\title{
Muslim Women's Haji Ali Movement in Mumbai: Reimagining Feminism and Piety in Islam
}

Dr Esita Sur ${ }^{+}$

\begin{abstract}
Muslim women's engagement with Islam through Haji Ali Movement in Mumbai highlights an interesting as well as conflicting encounters between Islam, feminism and women's rights. It not only disturbs the quintessential images of them but also opens up an array of possibilities to comprehend that Muslim women can develop their own critique of religion and cultural practices from within. The study argues that the Muslim women's Haji Ali movement or the mosque movement offers a surprising trade-off between Islam, feminism and women's rights by challenging the long-established idea that these are mutually exclusive entities and the distance cannot be bridged. Therefore, the study not only tries to find out the origin, nature and unique characteristics of the movement but also the new ways of exploring the dialogue between Muslim women's religious subjectivity, rights and feminism in India.
\end{abstract}

Keywords: Piety; Islamic Feminism; Gender Equality; Muslim Women; India

\footnotetext{
${ }^{+}$Assistant Professor, Scottish Church College, Kolkata, India Email: esitasur@rediffmail.com

(C) 2020 Sur. This is an Open Access article distributed under the terms of the Creative Commons Attribution License (http://creativecommons.org/licenses/by/2.0), which permits unrestricted use, distribution, and reproduction in any medium, provided the original work is properly cited.
} 


\section{Introduction}

The city of dreams-Mumbai (Maharashtra) had witnessed a new kind of mobilisation by Muslim women- the Haji Ali Movement. The movement for equal access in the dargah ${ }^{1}$ between men and women, more specifically for the entry to the sanctum of Saint Pir Haji Ali Shah Bukhari is known as Haji Ali movement. The dargah is known in the name of Saint Pir Haji Ali Shah Bukhari(R.A.). ${ }^{2}$ In dargah, there is no discrimination in terms of access based on caste, creed, religion, gender and community. The number of visitors increases from twenty to thirty thousand on the Thursdays, Fridays and Sundays. Dargah is a renowned pilgrimage site among the Muslims. Non-Muslims are also allowed to visit the sacred place. The whitecoloured Mughal structure can accommodate about ten to fifteen thousand people daily for offering their prayers and seeking the blessings of the Saint Pir Haji Ali Shah Bukhari (R.A.). In 2012, the Haji Ali Trust prohibited women's access to the sanctum on the ground that it is anti-Sharia, and Muslim women should not be allowed to the sanctum. The Muslim women activists from the Bharatiya Muslim Mahila Andolan $(\mathrm{BMMA})^{3}$ - an organisation for the Muslim women, by the Muslim women and of the Muslim women in Mumbai- came to know about this and did not accept this verdict in the name of Islam. Rather they decided to wage a struggle against the discrimination at the religious and spiritual level. They also observed that seven out of twelve dargahs were not allowing Muslim women and felt the need to mobilise the issue. This emerging newness in thought and activism has provoked the initiatives of taking up the study. This movement has also ignited another debate: can Muslim women's engagement with Islam empower them?

Whether women's participation and support for the socio-religious movement sustains their subordination to patriarchy or not, has been an integral part of feminist analysis. The Haji Ali movement (2014)-led by the BMMA in Mumbai has ignited the debate again. Moreover, this piety movement had asked for more nuanced ideas of agency - going beyond secular and religious; this movement further asks for investigating the notion of religious agency and women's rights in Islam critically. From a theoretical perspective, reimagining the core of feminism in Islam seems to be an interesting but difficult task. The relation between Islam and feminism has remained contentious on the grounds of oversimplification and reductionism. Mapping Muslim women's activism within feminism as a motivation or as a methodology is a difficult task, as feminism must stop conceiving itself as a natural political destination for all women. Rather than adopting a politics of inclusion, it has to develop a self-conscious politics of partiality and imagine itself as a limited political home, which does not absorb differences with a pre-given and pre-determined space but leaves room for ambivalence and ambiguity (Ang, 2003). Abdellatif and Ottaway's work (2007), which is based on the interviews of Islamist women activists involved in the women's wings of the organisations like Muslim Brotherhood (Egypt), Hezbollah mentioned that Islam and feminism are contradictory. And women's

\footnotetext{
${ }^{1}$ Dargahs are different from mosques. A mosque is a place of worship but a dargah is a shrine built over the grave of a revered and respected Sufi Saint. Generally the complex includes a mosque, kitchen, and the rooms for gathering. In India, dargahs are symbol of Islamic tradition and Sufi mystic knowledge as well as tradition. Muslims visit dargahs for Ziyarat', which means pious visit and closeness to Allah (Niaz and Soman, 2017).

${ }^{2}$ Haji Ali mosque has the tomb of Saint Pir Haji Ali Shah Bukhari. It has been described that while the saint was travelling to the holy city of Mecca, he passed away and his casket floated and landed up to the coast where the mosque was built in Mumbai.

${ }^{3}$ The Bharatiya Muslim Mahila Andolan (BMMA) is a Muslim women's organisation, which came into existence in 2007 in Maharashtra. This organisation has provided national platform for Muslim women and has always raised its voice against the practice of triple talaq, polygamy and mobilized women for their rights.
} 
issues, subjectivity and rights are very complex within the Islamist movements. The sense of empowerment, subjectivity and rights from within the religion takes a very different shape (Abdellatif and Ottaway, 2007). Therefore, the process of reinventing feminism in Islam demands an influential transition in feminist theorising: the move from stress on women's shared experience to stress on difference in experience based on religion, community and minority identity as well. Therefore, Haji Ali movement by Muslim women in Mumbai not only opens up a theoretical-practical discourse on Islamic feminism and piety movement together in India but also asks for a new orientation in the debates on Islam and Feminism. It compels us to revisit the contentious issues on Muslim women's engagement with feminism and Islam as these women can take the positions of 'actors' and 'subjects'. The multiple standpoints of these women develop their situated knowledge and worldviews from their experiences. Therefore, religious subjectivity of women is integrally related to these multiple standpoints. These new developments not only compel us to go beyond 'religious' and 'secular' but also to deconstruct the meaning of religious in the context of women's agency and empowerment. The argument of this study is: the interaction between Islam, feminism and Muslim women's religious subjectivity offers surprising insights for understanding women's empowerment and rights. Therefore, liberating Muslim women from the hegemony of Western feminism becomes an integral part of the project of reimagining feminism in Islam. The emerging Muslim women's movement against the arbitrary use of tin talaq, polygamy and domestic violence has raised many eyebrows including the Haji Ali movement; it has demanded revisiting the relationship between feminism and Islam. In this context, the study will attempt to explore a few questions: a) is it possible retheorising the core of feminism in Islam with special reference to Muslim women's Haji Ali movement in the Indian context? b) Is there any possibility to develop an alternative paradigm of Islamic Feminism in the Indian context? c) Can this revisit enable us to comprehend multiple standpoints and experiences of Muslim women? The study shall try to raise these questions and to some extent, answer them.

The study begins with a discussion of the theoretical context probing Muslim women's religious subjectivity and the question of agency and activism. Then it goes on to discuss Muslim women's rights in Islam. Following this, the study discusses BMMA's engagement with Islam and features of the Piety Movement in Mumbai, thereby locating Haji Ali Movement in Islamic Feminism.

\section{Muslim Women's Religious Subjectivity and Question of Agency and Activism: A Theoretical Framework}

A wide array of studies on Muslim women's religious subjectivity and activism motivates us to look at intersections of different notions of agency (Wadud, 1999; Kirmani, 2013; Lughod, 2013; Tschalaer, 2017). Western feminism never approves the fact that religion can be an instrument of empowerment, as it always posits the question of human agency into the watertight compartments of domination and autonomy (Bowden and Mummery 2012, p. 7). Following this theoretical framework, the dominant discourses have always defined Muslim women in terms of their passivity and victimhood, more specifically in terms of purdah, talaq, polygamy and domestic violence. The emerging Muslim women's movement in India exhibits that the dominant theoretical perspective ignores: a) Muslim women cannot be categorised as a homogenous entity; $b$ ) their lived experiences differ on the grounds of class, education, and sectarian affiliations; c) neither Muslim women nor Islam and patriarchy can be treated as fixed and absolute entities. This requires different theoretical frameworks, which shall help us in registering and understanding Muslim women's continuous negotiations with and resistance against the patriarchy. In this context, Rinaldo's (2014) reference to Cultural Toolkit approach, instrumental agency and categorisation of agency into pious, pious-critical and feminist 
agency becomes very significant for this discussion. Cultural Toolkit approach considers that religion provides a set of skills, schemes and resources, and women can use this for accomplishing their goals (Rinaldo, 2014, pp. 230-36). As Avishai highlights: it is all about doing religion rather than being recipients of it; she also mentioned that the idea of the agency has always been pitted against compliance and it is a false dichotomy (Avishai, 2008, pp. 140145). The notion of doing gender occurs when women construct their religious shelves through observance and conduct as well as negotiate with their multiple identities. As said by late Saba Mahmood, Professor of Anthropology at the University of California, women's negotiation with Islam may open up the 'capacity for action', which cannot be captured in the conventional framings of Islam and Gender (Avishai 2008,p. 150). However, many have critiqued the term use of religion in the Cultural Toolkit approach, and Rinaldo has warned us of its oversimplified use. Based on her ethnographic study on women's activism in Indonesia, she has also coined the term piouscritical agency of Muslim women; it explains women's agency to critically engage with Islam in the public sphere for rights and empowerment. She also made a distinction between pious and critical-pious agency (Rinaldo 2014, pp. 230-36). Indeed, in her famous work Politics of Piety (2005), Professor Saba Mahmood developed the notion of pious agency. Through her ethnographic work on Muslim women's Dawa movement in Egypt, she emphasised that compliance with religious texts and norms can also be a tool for empowerment for women and piety can be a source of agency. She not only challenged the liberal- humanist

\footnotetext{
${ }^{4}$ Maulana Muhammad Ilyas Kandhalawi in the Mewat province of India founded the Tablighi Jamaat in 1920. It is one of the most successful movements in the present times, and is strictly a non-political movement. The movement has spread to 150 countries. Each Jamaat has 8 to 20 members with one leader or Ameer, who is usually chosen by the members themselves before the actual journey. They stay in masjids (mosques) along the way, and preach to the people who come to the mosque. Tablighi Jamaat also includes women along with their
}

operations of the agency but also tried to look at the notion of agency in the context of nonWestern societies and beyond the simplistic ideas of submission and patriarchy. By following Judith Butler's (2007) theoretical framework, Mahmood mentions that the possibility of the agency is more visible within the structures of power, rather outside it. The repetitive performance of dominant norms and practices not only consolidates the regimes of power but also has the potentialities of destabilizing those norms and practices. This kind of framework goes beyond domination and subversion. Mahmood also argued that the participants in the Dawa movement (the mosque movement) in Egypt not only challenges the West-centric notions of governance and secularisation but also tried to establish the fact: Islam is not an abstract set of values and principles rather the core essence has to be materialised in everyday life of Muslims, beyond rituals (Mahmood, 2005, pp. 7-15). Therefore, the ethical formation of the subject becomes more important in this kind of definition of agency rather than an emancipatory model-breaking all the chains of exploitation. The components like docility, submission and collectivity constitute the notion of agency. The main difference between pious and critical-pious agency lies in women's capacity to engage with religion critically and publicly. However, Rinaldo (2013) warns that the pious agency has a tendency to make women more compliant with the normative-religious order but the degree of docility, submission and collectivity differ (Rinaldo, 2013). For example, there has been a difference between women's participation in Jammat-e-Islami (an Islamic political party) and Tablighi-Jamaat ${ }^{4}$ (Islamic Missionary Movement). It cannot be the same in

male companions such as husband and unmarriageable kin. Dawa tour is the main component of jamaat activities. The women perform several activities, in addition to their daily observance of regulatory religious prayers, such as Talim (reading/lesson circle), Bayan (religious sermon) during the dawa tour in order to cultivate their pious selfhoods. After the dawa tour, every follower is strongly recommended to observe the regulatory religious observances and prayers, and to organise and arrange the tablighi activities such as Talim and Bayan for other 
terms of varying degree of submission, docility and collectivity. Needless to mention, these discussions not only disturb the myths and binaries on passivity and victimhood on these women but also tries to establish that Muslim women can develop their critique of cultural practices and religious interpretations through individual and collective activism. They can also offer a nuanced understanding of feminist agency and activism.

While coming back to India and more specifically Muslim women's Haji Ali Movement, based on my five years of empirical study on Muslim women's activism in Mumbai, the notion of Muslim women's religious-critical agency becomes more appropriate in the Indian context. The findings of the work had substantiated this notion. It is also applicable for Muslim women's movement in India. The notion has been evolved to elaborate on the ways Muslim women have taken help from the religious text and resources critically and publicly to develop their notions of rights and empowerment within the religious framework. The idea of religious-critical agency is also significant in India, as many Muslim women's organisations like the BMMA in Mumbai combine secular ideas of rights and empowerment with religion. Most importantly, these women's organisations have not only engaged with Islam and women's rights but also have different standpoints on talaq, polygamy and other dimensions of Muslim women's lives. Moreover, these findings compel us to revisit the multiple theoretical positions on feminism, Muslim women's agency and activism and the recent Haji Ali movement by the BMMA in Mumbai highlights an interesting relationship between the Quranic interpretations, women's rights, spirituality and patriarchy. In this entire journey, the notion of Muslim women's Islamic subjectivity in their activism emerged as a powerful tool to comprehend their resistance and negotiations.

women in their neighborhoods and communities. The functioning of the tablighi jamaat highlights equality between men and women. However, it has to be mentioned that womens' participation in these

\section{Women's Rights and Islam: The Politics of Piety Movement}

The relationship between Islam and women's rights has been turbulent, as the misogynist interpretations on talaq (divorce), polygamy and domestic violence have always impacted women's rights in society. The Islamic legal discourse revolves around two central concepts: qiwamah (male authority over women) and darajah (male superiority). The classical understanding of Islamic legal resourcesShariah and figh - are based on the philosophy is that men have authority over women; they are the guardians and have the financial responsibilities of their wives. In return, they command obedience, authority and guardianship over women. It also incorporates sexual access and compensation that becomes husband's rights and wife's duty. This 'maintenance for obedience' equation was created through classical jurisprudence and prevalent in many Arab states. This has resulted in many difficulties, especially for women. These include men's unilateral and arbitrary right to divorce, women's unquestioned obedience to their husbands, the possibility of polygamy, husband's obligation to maintain the family and father's exclusive right of guardianship over their children. According to Ziba-Mir-Hosseini (2015), the notion of male authority and superiority has emerged as a legal postulate, which simply exists in its own right and ubiquitous, especially in the sphere of gender equality. However, it is not to deny that the classical jurists tried to safeguard women's interests but made no attempt to restrict men's unilateral right to talaq; it has repeatedly been mentioned that this practice is one of most sinful practices as mentioned by Prophet Mohammed.

Therefore, the juristic construction of qiwamah, developed in the context of the marriage contract, provided the ideological basis for gender inequality and other types of legal disparities (Hosseini, 2015 p. 17). Apart from the

movements has promoted them as repositories and key transmitters of the religious values and symbols of community identity (Mohammad, 1998, 320-322). 
socio-legal spheres, inequality and discrimination at the spiritual and religious leadership is also an essential dimension in this discourse. The vast literature on women and mosque highlights Muslim women's diverse experiences of engagement with Islam. Saudi Arabia decided of removing women from the area near $K a a b a^{5}$ and relocating them further away because of lack of space. However, later the decision was withdrawn (Badron, 2011, p. 337). In China, Muslim women's mosque and female ahong (religious leaders) have played an important role in transmitting the value of Islamic practice to Muslims, especially in terms of coping the challenges of new demands and aspirations as induced by globalisation. Muslim women's leadership and skills have been significant in terms of utilising their resources and goals (Jingjun and Jaschok, 2014, 641-643). Pamela Prickett (2015) also highlights in AfroAmerican communities in the USA, Muslim women face obstacles in the mosque participation (Prickett, 2015 pp. 56-58).

Therefore, women's access to religious leadership has always been challenging, and this polemical context has also given rise to the piety movements in Islamic and non-Islamic countries. Rinaldo (2010) used the term 'piety movement' and said that the movement tends to seek 'religious revival' in their religious teaching and practices towards theological conservatism. This piety movement is also based on a call to return to the glorious traditional past and women's individual and collective agency (Rinaldo, 2010). The globalising and modernising ${ }^{6}$ world with multilayered inequalities pose continuous challenges to them and this mobilisation based on religious teaching not only creates a space for refuge but also a collective identity. It also highlights that these women's quest for being modern and at the same time still being pious constitutes an integral part of this movement. This kind of mobilisation shows an exciting relationship between materialism, inequality, social change and isolation. Margot Badran

\footnotetext{
${ }^{5} \mathrm{Kaaba}$ is the great mosque of Mecca and located in Saudi Arabia. It is considered to be the most sacred site in Islam and for Muslims.
}

mentions that gender equality within the context of the mosque is a contentious issue. The mosque is a site of public communal worship and profound ritual practice for Muslims and a powerful symbol of equality (Badron, 2011 p. 337). In South Asian context, Amina Jamal (2009) through her work on Jamaat-e-Islami women in Pakistan has not only discussed Jamaat-e-Islami women's modern politicised Islamic subjectivity but also their polysemic relationship with modernity. The author has made an attempt to understand the ways through which jamaat women negotiate with their self-constructed images as pious women and their specific claims to act as modern subjects situated in the time of political and cultural modernity. Drawing on her fieldwork and interviews with women members of Jamaat-e-Islami, Jamal has established that contemporary jamaat women's public and political activism (not only philanthropic and educational) to profess a new engagement with modernity is the output of a complex web of local, national and global restructuring. The Jamaat-e Islami's engagement with modernity raises a dilemma between a modernist rereading of Islam and an Islamic re-reading of the modern, and contemporary jamaat women who embrace the idea of 'modern' while seeking to domesticate it within a religious discourse (Jamal, 2009). Recently Peshwar's famous Sunehri Masjid has opened the upper floor of the mosque for women for Friday prayers and sermon. The mosque had closed its door for women in 1996 due to militancy in Pakistan, but recently they had reviewed the decision (PTI, 2020). In countries like Bangladesh, women's mobilisation through religious groups is also visible.

In India, the rise of Muslim women's activism and critical engagement with Islam in the public domain has been a new development. The Haji Ali movement (2014) emerged as the larger part of Muslim women's movement in Mumbai; raises the question of these women's equal

\footnotetext{
6 There are various debates on globalisation and modernisation. However, this study intentionally debars from theorising the same.
} 
access to dargah and mazar (sanctum). This movement not only raised the issue of women's understanding of piety and spirituality but also politicised the question of gender equality and rights in Islam. The Haji Ali movement gained momentum in 2014. From the very beginning, the BMMA has raised its voice against the practice of tin talaq and in favour of codification of law for Muslim women's rights. The organisation was founded in 2007, and many ups and downs had impacted the graph of the organisation. This activism has also developed the idea of Muslim women's leadership, which was not only alien to our vocabulary but also has played an important role in voicing themselves. Therefore, the notion of gender equality in accessing the sacred spaces has emerged as a corollary to their ideological framework. The journey begins with an observation that Haji Ali Dargah Trust had restricted women's entry to sanctum or mazar. In their National Council Meeting on 11 March 2014, the members of the BMMA decided to file a Public Interest Litigation (PIL) in the Mumbai High Court. More than 10000 signatures were gathered from Maharashtra, Gujarat, Rajasthan, MP, Tamilnadu, Odhisa, West Bengal, Karnataka, UP and Delhi. The BMMA also realised that the political leadership has no will to address the issue, and the court is the only hope; the organisation had chosen to fight for itself. The PIL had both constitutional and religious arguments. At the one hand, the PIL had argued that denial of entry in the mazar was against the fundamental rights (Articles 14, 15, 25 and 26) ${ }^{7}$ on the other it had also drawn support from the verses and interpretations of Quran and hadith ${ }^{8}$. The BMMA not only argued about the violation of the right to equality but also raised the question: how does the Trust under the right to

\footnotetext{
7 These articles guarantee fundamental rights of Indian Citizens. Under the article 14 the state shall not deny to any person equality before law or the equal protection of law and under article 15 the Indian Constitution prohibits discriminations there based on caste, class, ethnicity, religion, sex and place of birth. Under article 25 , freedom of conscience and free profession, practice and propagation of religion is guaranteed and under article 26 deals with the right to religious denominations. However,
}

maintenance and manage their affairs under Article 25 and 26 can infringe someone's fundamental right? How does the institution's right to maintenance restrict someone's entry into the sacred place? Against their PIL, the All India Muslim Personal Law Board (AIMPLB) has also provided justifications on the decision to restrict women's mobility; these justifications were based on the rigid understanding of Islam. After a long struggle, BMMA had received victory as the honourable Apex Court had given verdict in favour of this case that the Trust could not violate women's fundamental rights and restrict their access into the mosque (Niaz \& Soman 2017, pp. 30-35). This movement has also thrown lights on the significant areas concerning Muslim women and religion and the rise of new kind of feminism in Islam.

\section{BMMA's Engagement with Islam and Features of the Piety Movement in Mumbai}

In this activism, the Muslim women activists always have taken help of religion for a constructive purpose. They have used the Quranic interpretations and hadith. They also argued that the Hanafi and Salafi School of jurisprudence had influenced the Trust's denial of women's entry into the mosque. However, there are multiple contestations on it and have continuously challenged their activism. For example, the secularist feminist argument believes that religion is always an instrument of oppression. And worshipping God cannot be the solution for women's problems. According to the BMMA, these positions do not take into account the everyday realities of ordinary women, more specifically Muslim women. The main objection comes from the conservative standpoint that argues that menstruating women are impure and cannot enter into the

our fundamental rights are not absolute and subjected to reasonable restrictions (Khurshid 2018, pp.13-17).

8 The word Hadith (plural Ahadith), meaning tale or communication, customarily refers to a narrative of the Prophet's life and practices. These records began to be compiled over a century after his death and were not completed until three hundred and more years later. Hadith demonstrates the relationship between texts and extra-textual contexts (contents and contexts) (Engineer 1999, 20-21). 
sacred spaces. Many conservative sections argue that women appear naked to the souls and so they should not visit the grave. However, they have no objection if men appear as naked to the souls. These logics acted as deterrents to stop women's entry to the Haji Ali. Against all these arguments, the BMMA fought on their religious and constitutional grounds. On the religious ground, the BMMA argued that Islam does not discriminate between men and women and it is the male-dominated interpretations of the text that has impacted their rights; on the constitutional ground, the organisation took the help of our fundamental rights and approached the Supreme Court of India for asserting their rights.

The Haji Ali Movement in India can be distinguished from the piety mobilisations taking place in the South Asian Countries like Pakistan and Bangladesh and other countries. This Haji Ali Movement has three dimensions: a) The BMMA's Haji Ali movement has inculcated a rights-based approach in the piety movement. This movement has asked for equal rights between men and women in Islam. This question of equal rights is not only evolved at the religious level but also at the constitutional level. This is a unique feature of this movement. It further leads to another important feature: this activism does not only address the question of religiosity at everyday life and practice but also incorporate the idea of equal rights in accessing the dargah through the form of protest politics. b) It has generally been argued that women's participation in the religious movement hardly increases their criticalconsciousness that enable them to raise questions against the patriarchal order and different forms of gender inequalities. The prevalence of critical-consciousness always helps us in exploring our socio-political and economic oppressions challenging the culture of silence. However, this movement has made a link between religious teaching and women's legal-constitutional rights and challenged the male-dominated interpretations of Islam. Most importantly, they have established that Islam can be gender-inclusive by interpreting the verses and taking help from the holy Quran.
Rather than surrendering to patriarchal interpretations, the Muslim women activists have made it clear that culture and Islam are not beyond contestations and mobilisations. This activism also highlighted the emergence of a radical moral agency among Muslim women, which has empowered them to make a critique of religion for asserting their rights but within the Islamic framework. Therefore, this movement relates to the notion of criticalreligious agency, which has been explained in the above-stated sections. c) This movement has also involved the Supreme Court to determine the question of equal access to the religious place. They have emphasised the individual relationship between women and Allah and also interacted with the democratic institutions for securing their rights. This Haji Ali Movement links rights and equality and the religious preaching on women's rights in Islam. The sole argument of the BMMA is: Islam does not discriminate between man and woman. Therefore, by seeking the intervention of the court, the movement has tried to create an alternative discourse on Islam, patriarchy and women. The BMMA's movement has also created mixed responses from within the community, which shows fragmented views on Muslim women's rights in Islam. Therefore, Haji Ali Movement highlights a need to revisit Islam from women's perspective. This can be understood based on the following features: a) It questions the conventional and rigid role of women as interpreted by the conservative leadership; b) through these new movements, women have powerfully argued the misogynist interpretations of the Quran and believes in the egalitarian principle of the text. Abu Bakr, one of the pillars of Islamic feminist discourse, has mentioned that there has been a divergence in the ways what Islam says about women's status and rights and the way misogynist interpretations, state politics and legislations in Muslim societies deal with this issue and the influence of the pre-Islamic thought cannot be ruled out in shaping these discourses (Bakr, 2017).

\section{Locating Haji Ali Movement in Islamic Feminism}


The emergence of Haji Ali movement also compels us to understand the ideological and theoretical framework behind it- Islamic feminism. The rise of Islamic feminism is not only confined to the Middle Eastern countries, but its genesis can also be traced in the Afro-Asian countries and immigrant and converted communities in the West. This kind of feminism tried to build a bridge between women's rights and Islam and argues that reinterpretations of the Quranic verses from a gendered perspective can secure women's rights. Islamic feminism argues that the Quran is based on the principle of equality between all human beings but the patriarchal interpretations, ideas, and practices have subverted the true meaning of the text. The Islamic Feminists believe in ljtihad and Tafsir (creative interpretation of the Quran). Reinterpretation of the Quranic verses from a gender-inclusive perspective can be found in the writings of Moroccan Islamist feminist Fatima Mernissi, Pakistani Scholar Riffat Hasan or Amina Wadud's famous book Women and Quran: Reading the Sacred Text from a Woman's Perspective(1999). These academic and scholarly ventures have not only created a new outlook on doing religion by women but also in locating women's rights in the religious framework. However, the rise of Islamic feminism can be traced in Iran and in the writings of Ziba Mir Hosseini, and Afsaneh Najmabadi who explained the rise of and context for Islamic feminism. Shahla Sherkat's Journal Zanan was first women's journal to deal with this Islamic feminist paradigm. This feminism has challenged the orthodox Islamic teachings on the differential rights and responsibilities of women and men by claiming women's rights to equality (Saliba, 2002 pp. 510).

The emerging Muslim women's movement and Haji Ali movement in India highlights a new type of Islamic feminism where exegesis (interpretations of the Quranic verses by the Islamic feminist scholars like Amina Wadud (1999), Omaima Abu Bakr (2017) and Asra Nomani (2016) is secondary, but by taking help from these interpretations, the Muslim women activists have brought up the relationship between Islam and women's rights in public. It was quite unimaginable in the past. These activists have also taken the help of the Quran and Hadith to support their arguments. For example, the activists took the help of Sahih Muslim, Volume 2, Book 4, Hadith 2130 to establish their claim that Islam does not encourage women's visit to graveyard, but it does not prohibit. It is indeed a kind of soft prohibition, which cannot be the sole reason for their debarment from the sanctum. A) Another critical dimension of Islamic feminism in India is: Muslim women activists have taken help of gender-sensitive interpretations; tried to develop their own meanings from the below. Challenging the misogynist interpretations has been an essential part of this scholarly and organisational activism. B) Another vital point that becomes significant in the context of Haji Ali movement and Islamic feminism is the question of women's religious authority and leadership. Haji Ali movement had tried to establish women's leadership in the domain of religion; it has shown that women can also go through Islam and Hadith to fight for their rights. Moreover, the BMMA has also established its Sharia Court and the notion of female quazis (religious leaders) who are trained in Islamic knowledge. In no religion, women's access to religious knowledge, authority and leadership has been smooth sailing, and it has always been under the control of male domination. When Amina Wadud led a mixed congregation for Friday prayer, it created huge hue and cry. Even her lecture at the University of Madras in Chennai was cancelled in 2013 due to stiff opposition from the community. Sharifa Khanam's initiative to build a women-centric mosque and jamaat in Pudukottai has invited her much criticism from within the community (Khanam, 2014). C) Another significant dimension of Islamic feminism in India is that based on this new gender-inclusive knowledge and meanings, Muslim women activists have given importance to the strategic issues like tin talaq, polygamy, nikah-halala, and women's equal rights to access the religious knowledge and mosque. I have used the term strategic because it has always challenged the power- 
hierarchy between men and women and the politics of Muslim women's subjugation in society. However, there are multiple standpoints within the Muslim women's movements on these issues. D) The question of 'religious' and 'secular' in Islamic feminism remains significant in the context of India. Making a distinction between religious and secular by the Muslim women activists become a challenging task in this majoritariandemocratic setup. While the Muslim women activists critique an Islamic practice (talaq) from within the religious framework, is it religious or secular? How do we look at the role of this critique based on reason in the Indian feminist activism context? While in the Islamic countries, the conflict between Islam and West becomes very visible, in India dynamics of rising right-wing forces and histories of communal violence have made the journey of Islamic feminism more difficult, as the feeling of insecure minority identity acts as another deterrent in mobilising Muslim women. As Badran (2011) mentioned, Islamic feminism eradicates the old binaries between religious and secular and between East and West. It closes the gap between and reveals the common concerns and goals for gender equality and social justice. The secular feminists in the Middle Eastern countries including Egypt always had the space for religion, and the Islamic feminist discourse in Iran and other countries has also been influenced by secular discourses and methodologies to extend their claims. However, it needs to be mentioned that even with the Islamic feminist discourse, there are points of differences between those who adhere to the gender-inclusive interpretations of Islam and rigid-totalitarian interpretations (Badron, 2011 pp. 311-313). Therefore, women's Haji Al Movement exhibits these nuances. While Muslim women activists have taken recourse to Islam to assert their rights, they have also gone to the Supreme Court for their constitutional rights. This activism also uniquely has blended religion and reason and motivates us to revisit the relationship between religion and feminism.

\section{Conclusion}

This kind of activism has evolved a very different kind of Islamic feminism, which is embedded in a particular context and activism. This also enables us to explore multiple shades and orientations of Muslim women's activism in the Indian context. Muslim women's struggle has evolved through a newly emerging understanding of Islam through a critique from within, which is more gender-sensitive than the traditional discourses on gender in Islam. Therefore, this kind of understanding considers them as more embedded identities in contexts rather than fixed categories of analysis, and it also disturbs the representation of Islam and women as hegemonic and monolithic categories. This kind of orientation compels us to revisit the relationship between religion and feminism and women's rights mediated through the idea of moral agency. Therefore, a new kind of feminism has evolved in the Indian context through Haji Ali movement in which women are developing their definition of rights and identity.

Moreover, the reasons behind the rise of Islamic feminism in the Middle East and the West have been different. The issues like the nature of the political field, rise of Islamisation, and migration had impacted the development. However, in India, it is a recent development; the majorityminority identity politics and history of communal violence have impacted the rise of Islamic feminism in India. Needless to say, the Muslim women activists have also faced challenges from the conservative section of society. Therefore, Muslim women's Haji Ali movement has created a new space for women in religion and culture and also opens up a space for more nuanced understanding in Islam, feminism and women's rights in India.

\section{References}

Abdellatif Omayma and Marina Ottaway (2007). Women in Islamist Movements: Toward an Islamist Model of Women's Activism. In Carnegie Papers (2), 3-13. Carnegie Middle East Center: Washington DC.

Avishai, Orit (2008). Doing religion in a secular world: Women in conservative religions and the question of agency. In Gender \& Society, 22 (2), 135-53. 
Amber, Srikant (2011, 9 December). All India Muslim Women Law Board. Retrieved from www.muslimwomenpersonallaws.com

Badron, Margot (2011). Feminism in Islam: Secular and Religious Convergences. England: Oneworld Publications.

Bakr, Abu Omaima (2017). Feminist and Islamic Perspectives: New Horizons of Knowledge and Reform. Cairo: The Women and Memory Forum.

Bowden, Peta and Jane Mummery (2012). Feminism. New Delhi: Rawat Publications.

Butler, Judith (2007). Gender Trouble: Feminism and the Subversion of Identity. New York: Routledge.

Engineer, Asghar Ali (1999). The Quran, Women and Modern Society. New Delhi: Sterling Publication Limited.

Esposito, L John (2011). What Everyone Needs to Know About Islam: Answers to Frequently Asked Questions. New Delhi: Oxford University Press.

Hosseini-Mir, Ziba (2015). Muslim Legal Tradition and the Challenge of Gender Equality. In Ziba, Mir-Hosseinid., Al,Sharmani., \& Jana, Rumminger (Eds.). Men in Charge? Rethinking Authority in Muslim Legal Tradition, (pp.13-43). London: Oneworld Publications.

len, Ang, (2003). 'I'm a Feminist but . . 'Other' Women and Postnational Femi- nism. In Reina Lewis and Sara Mills (Eds.). Feminist Postcolonial Theory: A Reader Edinburgh: Edinburgh University Press, pp. 40-50.

Jamal, Amina (2009). Feminist 'Selves' and Feminism's Others: Feminist Representations of Jamaat-e-Islami Women in Pakistan. Feminist Review, 81(1), 52-73.

Jingjun, Shui., \& Maria, Jaschok (2014). The Culture of 'Associational Leadership' in the Hui Muslim Women's Mosques of Central. In Asian Journal of Social Science, 42 (5), 641-656.

Retrieved from https://www.jstor.org/stable/43495824

Khanam, Sharifa (2004, 9 December).Women's Mousque Planned. Retrieved from www.stepswomensjamat.com

Khan, Shahnaz (2002). Muslim Women: Negotiations in the Third Space. In Therese, Saliba., Carolyn, Allen., \& Judith, A. Howard. (Eds.). Gender Politics and Islam (pp. 305-321). New Delhi: Orient Blacksawn.

Khurshid, Salman (2018). Triple Talaq: Examining Faith. New Delhi: Oxford University Press.

Kirmani, Nida (2013). Questioning the Muslim Woman: Identity and Insecurity in an Urban Indian Locality. New Delhi: Routledge.

Kumar, Nita (1994). Women as Subjects: South Asian Histories. New Delhi: Stree Publications.

Lughod, Lila-Abu (2013). Do Muslim Women Need Saving? Cambridge: Harvard University Press.

Mahmood, Saba (2005). Politics of Piety: The Islamic Revival and the Feminist Subject. Princeton: Princeton University Press.

Mahmood, Saba (2012). Feminist Theory, Agency and the Liberatory Subject: Some Reflections on the Islamic Revival in Egypt. In Raka Ray (Ed.), Handbook of Gender, (pp. 368402). New Delhi: Oxford University Press.

Mohammad, Talib (1998). The Tablighis in the Making of Muslim Identity. In Mushirul Hasan (Ed.), Islam Communities and the Nation: Muslim Identities in South Asia and Beyond, (pp. 307-340). New Delhi: Manohar Publishers.

Mahila Shakti Mandal (2012). My Struggle and My Leadership. Bharatiya Muslim Mahila Andolan: Mumbai.

Mernissi, Fatima (1991). The Veil and the Male Elite: A Feminist Interpretation of Women's Rights in Islam. New York: Addison-Wesley Publishing Company.

Niaz, Safia Noorjehan \& Zakia, Soman (2017). Reclaiming the Sacred Spaces: Muslim Women's struggle for Entry in Haji Ali Dargah. Notion Press: Chennai.

Niaz, Safia Noorjehan (2016). Women's Shariah Court: Muslim Women's Quest for Justice: An 
Alternative Dispute Resolution Forum For and By Muslim Women. Notion Press: Chennai.

Nomani, Asra(2016). Islamic Bill of Rights for Women in the Mosque. Retrieved from peprimer.com on 21.04.2016.

Prickett, Pamela J. T. (2015). Negotiating Gendered Religious Space: The Particularities of Patriarchy in an African American Mosque. Gender and Society, 29 (1), 51-72. Retrieved from https://www.jstor.org/stable/43669942

PTI. (2020). Now female worshippers can pray at Pakistan's famous Sunehri Masjid. Retrieved from www.telenganatoday.com on 07.03.2020.

Rinaldo, Rachel (2010). Women and Piety Movements. In Bryan S. Turner (Ed.), The New Blackwell Companion to the Sociology of Religion (pp. 584-605). Wiley Publishers: USA.

Rinaldo, Rachel (2013). Mobilizing Piety: Islam and Feminism in Indonesia. Oxford Publishing House: New Delhi.

Rinaldo, Rachel (2014). Pious and Critical: Muslim Women Activists and the Question of
Agency. Gender and Society, 28(6), 824-846.

Retrieved from

https://www.jstor.org/stable/43669923

Saliba, Therese, Carolyn, Allen, \& Judith, A. Howard (2002). Gender, Politics and Islam. New Delhi: Orient Longman.

Tschalaer, Hong Mengia (2017). Muslim Women's Quest for Justice: Gender, Law and Activism in India. Cambridge: Cambridge University Press.

Wadud, Amina (1999). Quran and Woman: Reading the Sacred Text from a Woman's Perspective. New Delhi: Oxford University Press.

\section{Conflict of Interest}

This is to certify that I do not bear any conflict that could benefit my interest with the journal or publication

\section{Acknowledgement}

I am very obliged to the insightful comments given by the referees, and it has enhanced the quality and perspectives of this article. 